
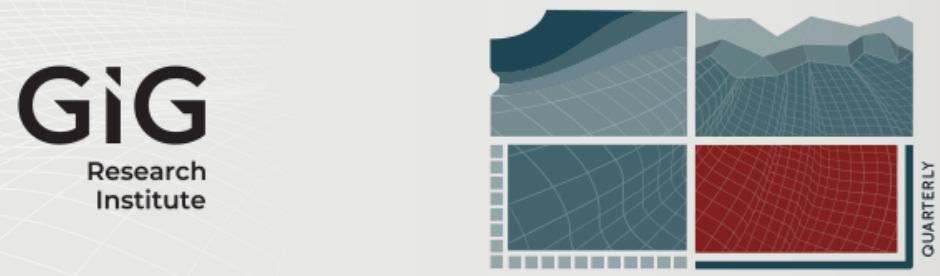

JOURNAL

OF

SUSTAINABLE

MINING

\title{
True cost of coal: coal mining industry and its associated environmental impacts on water resource development
}

Author(s) ORCID Identifier:

Noshin Masood (iD 0000-0003-2412-4940

Karen Hudson-Edwards (iD) 0000-0003-3965-2658

Follow this and additional works at: https://jsm.gig.eu/journal-of-sustainable-mining

Part of the Explosives Engineering Commons, Oil, Gas, and Energy Commons, and the Sustainability

\section{Commons}

\section{Recommended Citation}

Masood, Noshin; Hudson-Edwards, Karen; and Farooqi, Abida (2020) "True cost of coal: coal mining industry and its associated environmental impacts on water resource development," Journal of Sustainable Mining: Vol. 19 : Iss. 3 , Article 1.

Available at: https://doi.org/10.46873/2300-3960.1012

This Review is brought to you for free and open access by Journal of Sustainable Mining. It has been accepted for inclusion in Journal of Sustainable Mining by an authorized editor of Journal of Sustainable Mining. 


\title{
True cost of coal: coal mining industry and its associated environmental impacts on water resource development
}

\author{
Abstract \\ Coal is a strategic and essential resource that ensures quality of life, energy security and sustainable \\ development. Being the cheapest source of energy, it is the second after oil that is used to generate $40 \%$ \\ of the world's electricity. However, traditional and conventional coal fuel extraction can threaten human \\ health bycontaminating air and water, harming land, and contributing to global warming. The \\ environmental impacts associated with conventional methods of coal mining and consumption can \\ affect all components of the environment, and these impacts may be beneficial or harmful, permanent or \\ temporary, repairable or irreparable, and reversible or irreversible in nature. These effects require \\ considering of changing the production and consumption of coalwithin a technological framework. Coal \\ mining operationscan cause both quantitative and qualitative impacts on water systems in and around \\ mining areas. This paper reviews the impacts of coal mining on water resource development. Land \\ subsidence, disruption of hydrological channels, flooding, and contamination of water resources and \\ depletion of water table are the major measurable impacts of mining activity on the hydrological \\ environment.
}

\section{Keywords}

Coal mining; Coal energy; Groundwater quality; Environmental impacts; Sustainable development

\section{Creative Commons License}

c) (1)

This work is licensed under a Creative Commons Attribution 4.0 License. 


\title{
True cost of coal: Coal mining industry and its associated environmental impacts on water resource development
}

\author{
Noshin Masood ${ }^{a}$, Karen Hudson-Edwards ${ }^{b}$, Abida Farooqi ${ }^{a, *}$ \\ ${ }^{a}$ Environmental Geochemistry Laboratory, Department of Environmental Sciences, Faculty of Biological Sciences, Quaid-i-Azam \\ University, Islamabad, PO 45320, Pakistan \\ ${ }^{\mathrm{b}}$ Camborne School of Mines and Environment and Sustainability Institute, University of Exeter, Tremough Campus, Penryn, TR10 9EZ, \\ UK
}

\begin{abstract}
Coal is a strategic and essential resource that ensures quality of life, energy security and sustainable development. Being the cheapest source of energy, it is the second after oil that is used to generate $40 \%$ of the world's electricity. However, traditional and conventional coal fuel extraction can threaten human health bycontaminating air and water, harming land, and contributing to global warming. The environmental impacts associated with conventional methods of coal mining and consumption can affect all components of the environment, and these impacts may be beneficial or harmful, permanent or temporary, repairable or irreparable, and reversible or irreversible in nature. These effects require considering of changing the production and consumption of coalwithin a technological framework. Coal mining operationscan cause both quantitative and qualitative impacts on water systems in and around mining areas. This paper reviews the impacts of coal mining on water resource development. Land subsidence, disruption of hydrological channels, flooding, and contamination of water resources and depletion of water table are the major measurable impacts of mining activity on the hydrological environment.
\end{abstract}

Keywords: coal mining, coal energy, groundwater quality, environmental impacts, sustainable development

\section{Introduction}

$\mathrm{T}$ he development of an economy is linked with a country's natural resource potential. These natural resources and environment are the primary factors influencing sustainable development. For decades, mining and sustainable development have been the focus of significant research for academic and public policy institutes worldwide [1,2]. Coal, being the cheapest fuel, is the strategic resource in development, energy security. Its economical pricing and its geographical distribution patterns render it one of the most favored and dominant energy source for both developing and developed countries (e.g., Australia, China, Germany, India, Japan, South Africa and the US) [3]. Among the natural resources, coal is one of the three main energy resourcesand used to generate $40 \%$ of the world's electricity [4]. This coal consumption seems to be amplified to $50 \%$ by 2030 . Since 1961 coal and coal based power plants have brought prosperity toglobalpower and energy sectorsand soonseveral hundred millions people will get coal-generated for the very first time in thehistory [3]. However, the mining and processing of coal has had significant negative impacts on the environment, human health, and climate change. In 2012, for example, the global extraction of 7.8 billion tons of coal [5] contributed to $39 \%$ of global $\mathrm{CO}_{2}$ andmethane production and to the deaths of millions of miners [6-8]. The air quality of coal mining areas around Jharkand, India from 2010 to 2011 greatly exceeded recommended concentrations of

Received 29 November 2019; revised 25 February 2020; accepted 26 February 2020.

Available online 28 September 2020.

* Corresponding author.

E-mail addresses: abida.farrukh@gmail.com, afarooqi@qau.edu.pk (A. Farooqi). 
$\mathrm{NO}_{2}, \mathrm{SO}_{2}$ and total suspended particles (TSPs) [9]. Undergroundcoal mining has converted the Appalachian mountains of West Virginia into valleys and turned its streams orange with acidic water [3].

Coal and water are two interrelated resources. Water is the most crucial component in mining industry that is consumed at all stages of a mine's life [10]. The hydrological consequences of coal mining are significant and complex, as mining can lower water tables, disturbing natural drainage patterns, and can cause surfaceand sub-surface aqueous contamination. The effects of exploration and mining activities on both water quantity and quality have been documented in a variety of studies [2,11-13]. Water table instability, potential flooding, uncontrolled disposal and collapse of waste dumps are significant challenges to the sustainable mining of coal. Despite the fact that coal mining is globally a relatively small water consumer, 7 to $9 \mathrm{BCM}$ (billion cubic meter) of water are consumed annually [14]. In China, annually 120 billion- $\mathrm{m}^{3}$ water (i.e. $20 \%$ of total national consumption) is used in the underground and surface coal mining. Whereas on average extraction of one coal produced $4 \mathrm{~m}^{3}$ wastewater [15]. In the Angul-Talcher region of Odisha (India) 86.26 million- $\mathrm{m}^{3}$ of water is extracted from river systems for the coal industry [16]. The legacy of mining activity due to poor extraction practices, improper water disposal, and mine tailingscan also negatively impact the water cycle $[17,18]$. In China, for example, the extraction of one ton coal depletes water resources by $1.32 \mathrm{~m}^{3}$, and causes the contamination of $0.88 \mathrm{~m}^{3}$ of water bodies and damage to $0.17 \mathrm{~m}^{3}$ of ecological environments with a consequent economic loss of about 50.61 Yuan [19]. The utilization of one ton of coal in thermal power sectors costs 86.61 Yuan and depletes water resources by $26.35 \mathrm{~m}^{3}$ [19]. The coal industry does paycompensation costs. In China this industry pays asewage discharge fee of 1.4 Yuan per equivalent to the soil erosion fee, water resource fee of $0.1-1.6 \mathrm{Yuan} / \mathrm{m}^{3}$, anda compensation fee against soil erosion and soil conservation of $0.5-1.5 \mathrm{Yuan} / \mathrm{t}$ [19]. Yet it requires the revision in real terms to establish a true coal-related water resource cost. Overall, more than $50 \%$ of the world's largest coal producers or consumers face water stress in their region. For example, major coal producers such as Japan, Indonesiaand South Korea have drastically increased water consumption due to coal mining, and are designated as highly water stressed countries [20]. Agricultural, fishery and tourism industries are also affected by coal mining [21-25]. For instance, Acid mine drainage (AMD) from abandoned coal mines in Pennsylvania degrade $8800 \mathrm{~km}$ of streams and rivers, resulting in annual loss of 653 million Yuansfromthe fishery industry [26].

The aim of this review article is to determine the trends and impacts of coal mining on water resource development (i.e., the inherent cost of coal). The information presented will highlight the causes and processes that contaminate waters and cause fracturing and subsidence of overlying strata, disrupting hydrological pathways. This review will help to formulate environmentally sustainable coal mining operations.

\subsection{Coal mining effects on water quality}

Coal mining can pose serious threats to surface and sub-surface waterquality, and it can also impact on drinking water availability in many mining areas. It affects watersboth physically and chemically. Physically it causes silting and decline of water quantity. Chemically coal mining can cause AMD and cause the release of metallic and (metal(loid)) compounds to receiving waters (Fig. 1).

Coal resources are extracted by surface and underground mining. Both of these activities can disrupt aquifers, resulting in increased rates of

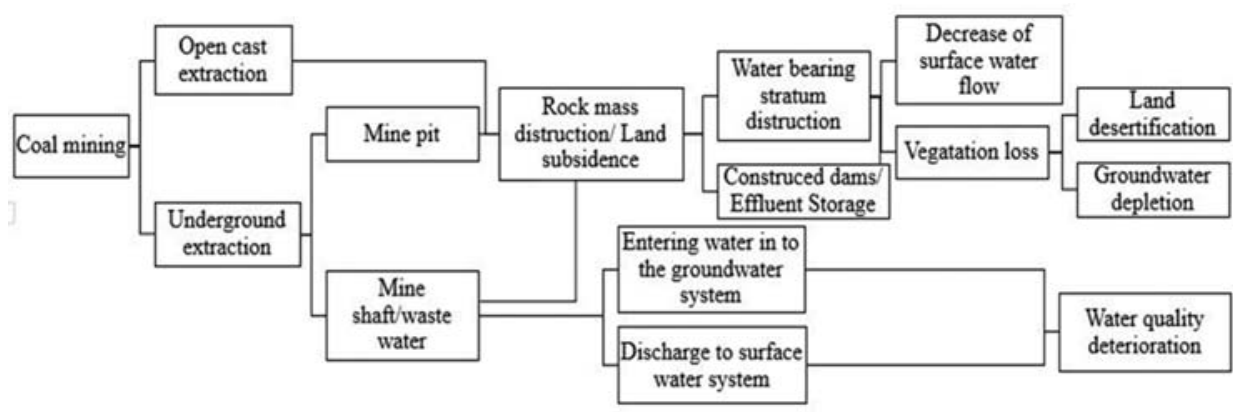

Fig. 1. Impacts of coal mining activities on water resource development (modified from Ref. [19]). 
evaporation, permeability and contamination [27]. A highly complex interaction exists between coal extraction and water resources, leading to potential impacts on both hydrology and water quality at each stage of a mine's life.

A five year intensive study conducted in Pennsylvania showedthat about $9 \%$ of the total water supplies were directly affected by the coal mininginduced subsidence in the region [24]. Various natural features and ways by which mining operations contaminate water sources comprised of types of aquifers and rocks, geochemistry of the coal seam its stratum and adjunct aquifers, the topography of the area.

Hydro-geochemical processes including; cation exchange reactions, water-rock interaction, and water flow also affects geochemistry and evolution of these aquifers [28]. Coal extraction can enhance the salinity (conductivity) of runoff and watersheds $[29,30]$, runoff and base flow [30,31], sediment, metals, sulfate water and $\mathrm{pH}$ as a result of acid neutralizing processes $[32,33]$ and seam bed erosion [34]. Approximately $40 \%$ of the groundwater of Northern Province of China is affected by coal mining activities [28]. In comparison, water contamination rateof coal mining region of South China is 2.4 fold than the average national level, whereas it is 3.5 times than the northern regions of Inner Mongolia, Ningxia, Shaanxi, and Gansu [19].

Another important environmental concern of coal mining is the drainage water [35]. Coal mining in the entire Appalachian mountain range of West Virginia has been shown to make its streams run orange with acidic water [3]. Abandoned coal mines in Scotland are considered to be the second most significant surface water quality threat [36]. Elevated concentrations of $\mathrm{Hg}$ and other physicochemical parameters (TDS, $\mathrm{Na}^{+}, \mathrm{F}^{-}, \mathrm{SO}_{4}^{2}$, and trace elements) were also reported in the Thar coal aquifers of Sindh (Pakistan) [37]. Acid mine drainage can also affect agricultural yield; for instance, fields of the Barapukuria coal mining area (Bangladesh) irrigated with coal mine drainage had low yield of rice [17].

The produced mine water can have significant environmental impacts. In China, coal and iron producing mines produce 1.2 billion tons/year of waste water [38]. This mine water undergoes inorganic and microbial oxidation when comes in contact with water and atmospheric oxygen, and produces ferric hydroxide and S-rich acid known as acid mine drainage (AMD). It affects the water quality in term of lowering its $\mathrm{pH}$, and increasing its total solids contents (TDS), trace elements and sulfate concentrations [39-41]. The volumes produced can also be large: 41 coal mines in Korea, for example, produce $141,000 \mathrm{~m}^{3} /$ day AMD [42]. The abandoned mines of Young Dong and Young Jin mine (Gangneung coalfield, Korea) discharge 5000 $\mathrm{m}^{3} \mathrm{~d}^{-1}$ mine water that severely deteriorate water quality [43]. Around $76486 \mathrm{ha}$ of land and $4989 \mathrm{~km}$ of streams covering 44 counties of Pennsylvania are also affected by AMD [44]. In the USA, abandoned coal mines polluted over $14,484 \mathrm{~km}$ of streams and 0.44 million hectares of land with mine water [44].

The coal mining industry also produces tons of solid waste [45]. It is one of the biggest source of solid waste and accounted for $40 \%$ of the total solid waste generated in China [44]. These coal wastes cover an area of 15,000 ha [46]. Coal waste rock dumps generally contain sulfideand iron minerals e.g. pyrite $\left(\mathrm{FeS}_{2}\right)$, chalcopyrite $\left(\mathrm{CuFeS}_{2}\right)$, sphalerite $(\mathrm{Zn}, \mathrm{Fe}) \mathrm{S}$, galena $(\mathrm{PbS})$, troilite $(\mathrm{FeS})$, and pyrrhotite $(\mathrm{FeS})$, siderite $\left(\mathrm{FeCO}_{3}\right)$, illite $\left(\mathrm{K}_{3} \mathrm{H}_{3} \mathrm{O}\right)(\mathrm{Al}, \mathrm{Mg}, \mathrm{Fe})_{2}(-$ $\mathrm{Si}, \mathrm{Al})_{4} \mathrm{O}_{10}\left[(\mathrm{OH})_{2}\left(\mathrm{H}_{2} \mathrm{O}\right)\right.$, ankerite $(\mathrm{Ca}(\mathrm{Fe}, \mathrm{Mg}, \mathrm{Mn})$ $\left.\left(\mathrm{CO}_{3}\right)_{2}\right)$ [47,48]. Under oxidizing conditions, these sulfide minerals break down followed the following acid forming equation (Eq. (1)).

$$
\mathrm{FeS}_{2}+3.75 \mathrm{O}_{2}+3.5 \mathrm{H}_{2} \mathrm{O}=\mathrm{Fe}(\mathrm{OH})_{3}+2 \mathrm{SO}_{4}^{2-}+
$$
$4 \mathrm{H}^{+}$

Acid mine drainage acidifies nearby water and soil bodies (Table 1). For instance, low $\mathrm{pH}$ and high TDS of the Olifants River (South Africa) and groundwater contamination of salt range of Chakwal (Pakistan) are the result of such reactions, which in turn were attributed to intensive coal mining $[63,64]$. Coal mining-derived AMD can also have relatively high concentrations of metal(loids) such as $\mathrm{Ag}$, As, Cd, Cu, Cr, $\mathrm{Hg}, \mathrm{Mn}, \mathrm{Mo}, \mathrm{Ni}, \mathrm{Pb}, \mathrm{Sb}$, $\mathrm{Se}, \mathrm{Zn}, \mathrm{U}$ and V [41]. Significant correlations of sulfur with these elementssuggests that the degradation of other sulfide minerals, which are the constituents of coal, likely occurs [48]. For example, groundwater in the Indian Coal Basin is highlycontaminated with such metalloids as a result of AMD, mine tailings and leachate [59]. The aqueous $\mathrm{pH}$, temperature, content of $\mathrm{Fe}$ and $\mathrm{O}_{2}$, water saturation rate, chemical activation energy and rate of biological degradation were shown to be the primary controls on AMD generation [65].

Coal mining-derived AMDcan be neutralized [66] by either a) inhibiting the acid generation reactionsexposure of oxygen and water to pyrite and other sulfide minerals or b) reactions with carbonates (aragonite, calcite, dolomite, and siderite), silicates, aluminosilicates, and hydroxides of $\mathrm{Fe}$ and $\mathrm{Al}$ (Eq. (2)) [45]. Such alkaline mine waters are produced, for example, by neutralization and coal mining-dervied AMD in Scotland [33]. 


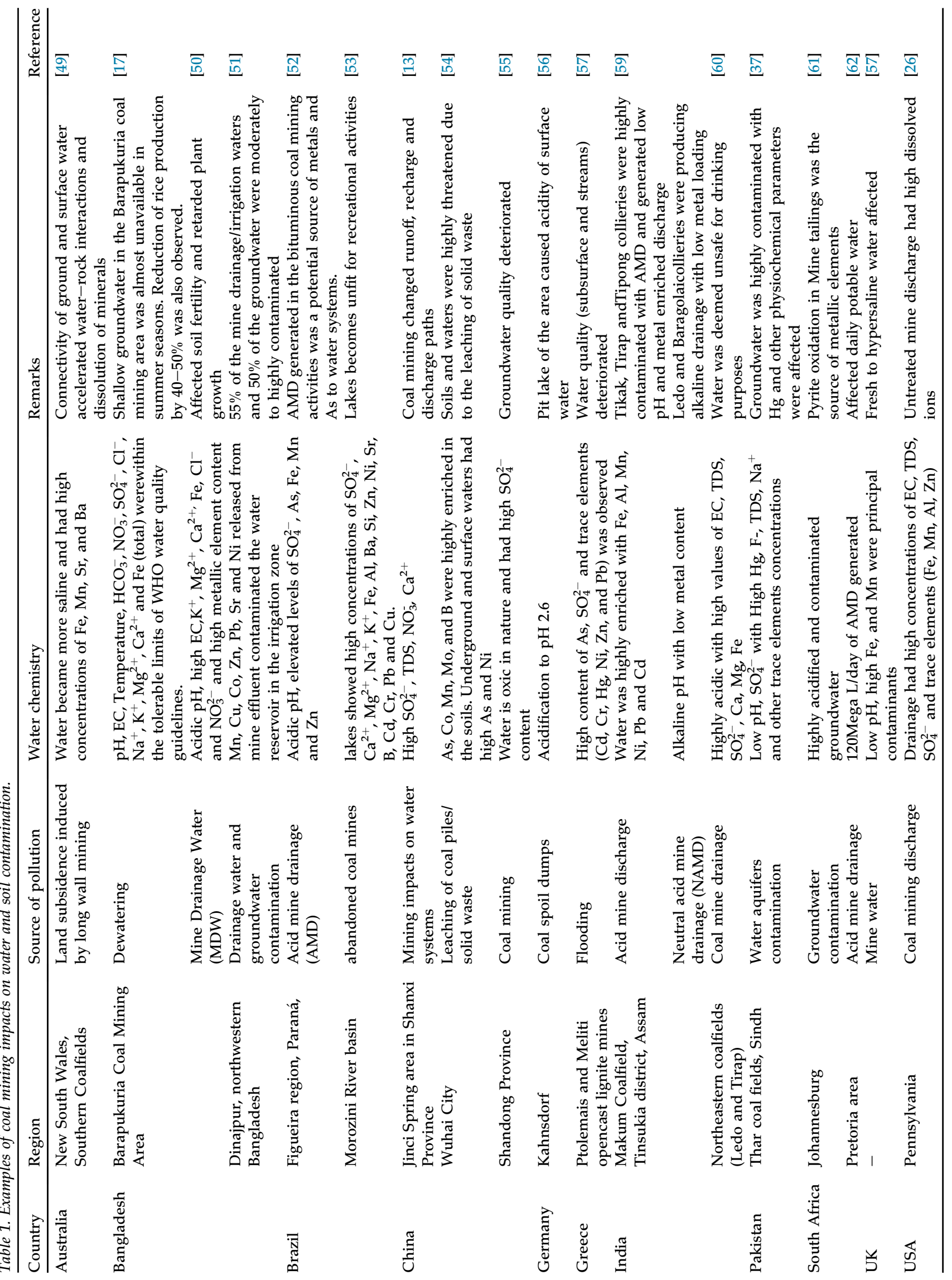


Table 2. Types and magnitude of land subsidence in coal mining regions.

\begin{tabular}{|c|c|c|c|c|c|}
\hline Country/Region & Year & Area & Subsidence rate $(\mathrm{mm})$ & Type of subsidence & Reference \\
\hline Australia & - & New South Wales, Southern Coalfields & 25 & Horizontal & {$[49,68]$} \\
\hline Belgium & 1992-2010 & Winterslag and Zwartberg & 200 & Vertical & [69] \\
\hline Bangladesh & 2014 & Barapukuria, Dinajpur & $100-890$ & Trough & [70] \\
\hline Canada & $2004-2007$ & $\begin{array}{l}\text { Frank Slide area, } \\
\text { Alberta }\end{array}$ & 3.1 & - & [71] \\
\hline \multirow[t]{3}{*}{ China } & 2012 & Guqiao & 158 & - & [72] \\
\hline & - & Huainan & 7800 & - & [73] \\
\hline & 1998-2008 & Wujiabao and Xiayuan & $798.37-763.18$ & - & [13] \\
\hline Colombia & - & $\begin{array}{l}\text { Venecia and Bolombolo Regions, } \\
\text { Antioquia }\end{array}$ & 730 & - & [74] \\
\hline Czech Republic & 2007 & DoubravaVrchovec & 450 & Horizontal & [75] \\
\hline England & 1983-2005 & DoubravaUjala & 34 & Horizontal & [76] \\
\hline \multirow[t]{2}{*}{ Germany } & Early 19th century & Ruhr district & $20,000-24,000$ & - & [77] \\
\hline & 1998-2015 & Wurm valley & 51 & - & [78] \\
\hline India & 2007 & Jharia & $0-27.8$ & - & [79] \\
\hline Indonesia & $2005-2006$ & East Kalimantan & 400 & Vertical & [80] \\
\hline Korea & 1992-1998 & Samchuck & 220 & Vertical & [81] \\
\hline South Korea & 2013 & - & 3900 & $\begin{array}{l}\text { sink-hole \& trough } \\
\text { subsidence }\end{array}$ & [82] \\
\hline Taiwan & $1972-2012$ & $\begin{array}{l}\text { Changhua, Yunlin, Chiayi, and } \\
\text { Pingdong in Central and Southern } \\
\text { Taiwan }\end{array}$ & $12-34$ & - & [83] \\
\hline
\end{tabular}

$\mathrm{CaCO}_{3}+\mathrm{H}^{+}=\mathrm{Ca}^{2+}+\mathrm{HCO}_{3}^{-}$

Carbonate-AMD reactions such as those in Eq. (2) are associated with the release of high content of $\mathrm{Fe}$, $\mathrm{Mn}, \mathrm{Ca}^{2+}$, and $\mathrm{Mg}^{2+}$ [67]. Coal mining associated impacts that deteriorate groundwater quality are enlisted in Table 1.

\subsection{Effects of land subsidence on regional water systems}

Neotectonic movements of underground masses can result in subsidence, sinkholes and uplifting of infrastructures. During surface and/or underground mining operations, 100s of meters of overlaying layers of soil or rock referred to as 'mine spoil' are removed. The propagation of deformed and displaced waste rocks induces pressures on larger surface subsidence, changes the permeability, porosity and hydraulic gradient of strata, and water table levels. Coal mining induced land subsidence incidents in different regions are reported in Table 2.

Land subsidence due to coal mining operations is one of the important factors affecting surface structures and water resources. Subsidence is a surface and subsurface, horizontal and/or vertical sliding of the ground surface into mine voids that can be small or large scale, generalized or localized in nature (Table 1). Land sliding and subsidence are mainly induced by in situ pressure, underground water regime, topography, rate and method of extraction [84]. Long wall mining either in active way or by passive way (due to residual subsidence) have more severe magnitude of subsidence as compared to open pit mining method [85,86].

In China $92 \%$ of the total coal is extracted by underground caving mining methods. This intensive subsurface coal mining in densely populated coal basins has caused severe land subsidence, resulting in ecological, economic and environmental concerns $[46,87]$. It has been estimated that production of 10,000 tons of coal in China leads towards an estimated land subsidence of $0.2-33$ ha [44]. It has been predicted that over-extraction of coal in China will expand the land subsidence impacts by $2 \times 10^{4} \mathrm{ha} /$ year [88]. In Shanxi Province, China, it has been reported that out of $20,000 \mathrm{~km}^{2}$ of coal mining affected land, around $650 \mathrm{~km}^{2}$ of the area experienced land subsidence [89]. An area of $2000 \mathrm{~km}^{2}$ in Taiwan also experienced subsidence of $1.2-3.2 \mathrm{~m}$ [83]. In the case of India, highly volatile and bituminous coal at the Barapukuria Mine occurs stratigraphically beneath the DupiTila (water-bearing) Formation, which is declared as naturally vulnerable, due to sinking and subsidence incidents in the area.

The magnitude of subsidence is much more severe in karst areas. For example, an area of 500 ha in Fankou mines (Guangdong), 2000 ha of Enkou mining area (Hunan), 294,000 ha of Shanxi province were experiencedland sinking [90]. Furthermore, Shanxi Province in China the land slinkingdue to coal mining increase by 9400 ha each year [90].

In South Korea, 548 subsidence cases with an average rate of $3.9 \mathrm{~m}$ were reported for 349 coal 
Table 3. Water depletion status of different coal mining regions around the globe.

\begin{tabular}{|c|c|c|c|c|}
\hline Country & Date year & Area & Water table depletion (m) & Reference \\
\hline Bangladesh & $2001-2011$ & Barapukuria, Dinajpur & $>5$ & [17] \\
\hline \multirow[t]{3}{*}{ India } & 2013 & Jharia, Jharkhand & $1.29-6.9$ & [99] \\
\hline & - & Ranigang, Barddhaman, West Bangal & $7-18$ & - \\
\hline & 2014 & Angul-Talcher belt, Odisha & $7-9$ & [100] \\
\hline \multirow[t]{6}{*}{ China } & 2013 & North China & $0.02-0.028$ & [40] \\
\hline & 2000-2014 & Shenmu-Fugu & $>10$ & [96] \\
\hline & & Yulin-Shenmu & $2-6$ & \\
\hline & 1952-1993 & Jiaozuo, Henan province & 34 & [44] \\
\hline & - & Yongcheng mining area & $5-10$ & [101] \\
\hline & 1994-2005 & Jinci spring area & 18.45 & [13] \\
\hline \multirow[t]{2}{*}{ Colombia } & 2020 & Plan Bonito & 14.8 & [4] \\
\hline & 2014 & Cesar & 10 & \\
\hline \multirow[t]{2}{*}{ England } & 1980-2006 & Oxton Bogs & 2 & [18] \\
\hline & 1980-2006 & Dover Beck catchment & 4 & \\
\hline
\end{tabular}

mines [82]. The subsidence is due to the steep slope (at an angle of $40^{\circ}$ ) of mining site and the slant chute block caving excavation method. Similarly, long wall coal mining since the 1982 in Australia region has caused infrastructure damagedue to landslides. The fracturing and sinking of overlaying strata generally increases water conductivity and water-rock interaction. In the Rivulet Catchment in Sydney, Australia, for example, high concentrations of metallic elements in water were proposed to bedue to the increased water-rock interactions as a result of fractures and faults [91]. Land subsidence also changes the slope of the surface that affect drainage pattern by disturbing its water flow channel [70]. It can also reduce the thickness of aquifers, modify the natural retention period, and create a permanent water logging situation. In the Ruhr district, annual subsidence of $4.7-8.5 \mathrm{~mm}$ affects water channels of the EmscherRiver catchment area [77]. Subsidence also increased the silt-trapping efficiency of the floodplains of Wurm River (Western Germany) [78].

Land subsidence affects surface water by disruptingand diverting river channels, fracturing riverbeds, causing flooding and ponding, decreasing runoff rates, and inducing mixing of surface and groundwaters, resulting into water quality deterioration [92]. For example, underground mining as result of surface subsidence produced subsidence water ponds in Huainan Province (China) that's are highly contaminated with $\mathrm{Cr}, \mathrm{Co}, \mathrm{Ni}$, and $\mathrm{As}$ [93].

\subsection{Disruption of hydrological pathways}

Mining activities require smaller quantities of water than mineral processing activities (dust suppression, cooling of equipment and fire control etc.), but large-scale movement of heavy machinery and material during the development of mining operations can significantly disrupt the natural landscape and affect the water regime of an area [10]. The major factors that control water flow include the hydrogeology of the area, porosity, permeability, landscape, topography, coal depth and height, and sizes of mines. These factors further affect water recharge, discharge and its storage capacity. In case of Barapukuria (Bangladesh) less permeable soils of subsidized areas around the coal mines resulted into artificial lakes which further reduce water table and deteriorated water quality in the area [70]. Wherever, rocks deformation due to continuous mining significantly changes topography and effect transmissivity by disconnecting the local flow patterns and storage capacities of aquifers. For example, coal mine tailings that are stored in drystacks, backfilled into mines, disposed in constructed dams or in discharged to nearby surface water environments, can result in reductions in runoff [94] In China, decreases in river runoff of 5.72 million $\mathrm{m}^{3}$ have been attributed to coal mining. A study conducted in the Gujiao, China, mining areas from 1981 to 1990 showed that river runoff was reduced by 11.13 million $\mathrm{m}^{3} / \mathrm{y}$ for each ton of coal mined. From 1990 to 2000 this figure increased to 21.77 million $\mathrm{m}^{3} / \mathrm{y}$, and from 2001 to 2008 it increased further to 37.99 million $\mathrm{m}^{3} /$ year [95]. Ahuge decline in Tuwei and Kuye River of China flowwas also observed during the spell of 2004-2014 [96]. Decline in water availability as a result of decrease runoff, was also observed in the Olifants River in South Africa [63]. The resultant reduction in surface runoff was linked with extensive increase in coal extraction and poor mining practices.

Groundwater in valley fills has long reaction times, resulting in higher amounts of mineral dissolution and increase TDS concentrations. This has been reported for mine inflowsand outflows of Chakwal, Pakistan [64] Similarly, prolonged coal mining in the catchments of Witbank Dam, South 


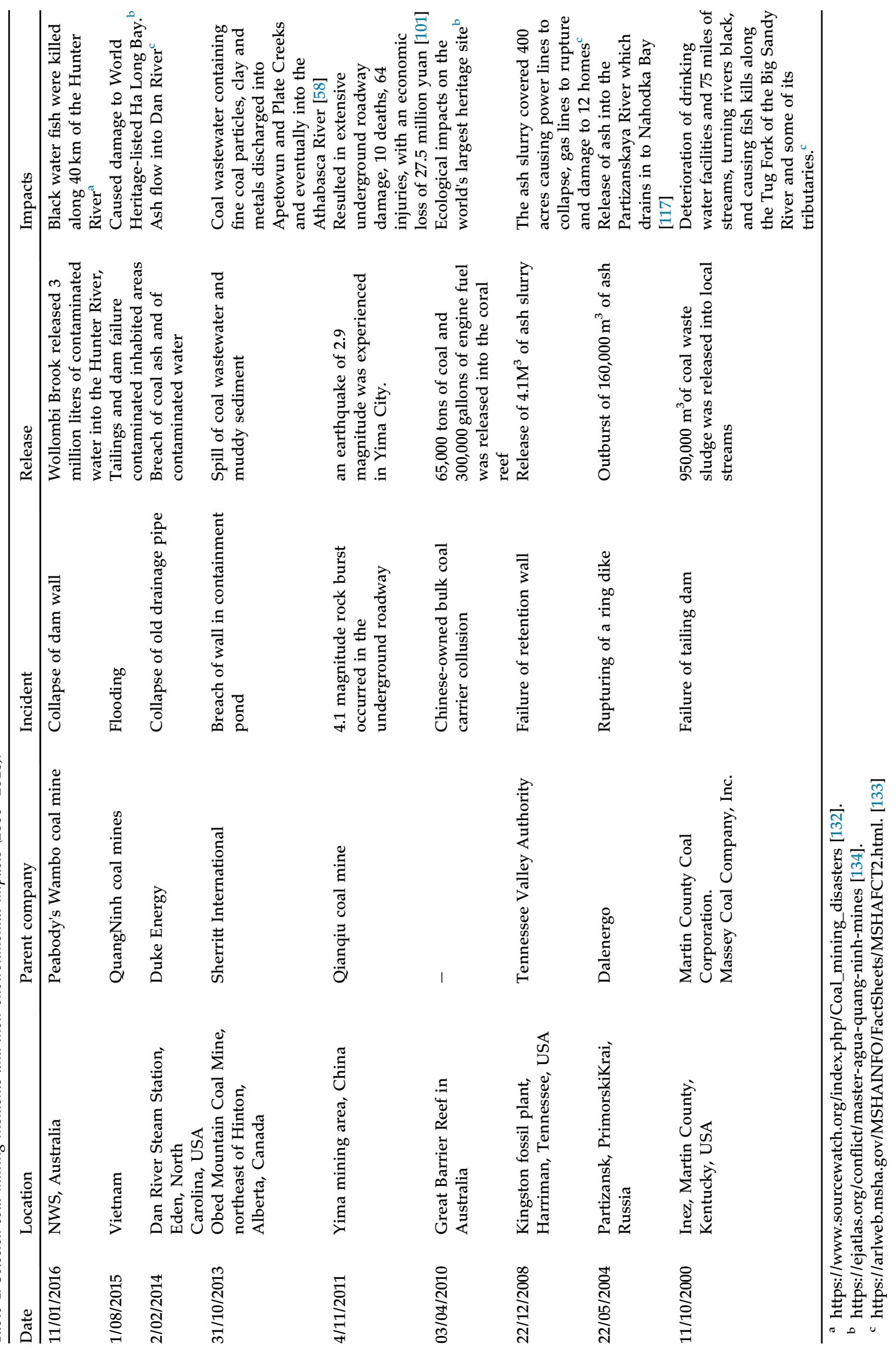


Africa has resutled in high amounts of turbidity and TDS, and decreases in the storage capacity of valley fills [63].

In some cases, intensive coal mining results in loss of vegetation at both mined and valley fill areas that affects the evapotranspiration rate of the hydrological cycle, as well as the storage capacity of unconsolidated aquifers.

Ground deformations as a result of surface and underground sinking may facilitate the infiltration. The combination of groundwater infiltration, rainfall and runoff can lead to substantial influx of water, resulting into flooding of open pits, the formation of pit lakes and inundation of underground mines. This has been seen in case of Barapukuria Coal Mining area (Bangladesh) [70]. Preventionof such inrushes may require active pumping, particularly when the mines are located in regions with high rainfall and low evaporation rates.

\subsection{Depression of water table around the dewatered zone}

Water table levelsare generally controlledby water abstraction patterns. Groundwater aquifers around coal mining areas are generally deeper and have visible declines with the passage of time. To facilitate underground coal mining, a large volume of overburden strata is often removed. Dumping of these mine tailings and heavy mechanics requires for mining operations caused soil compaction that affect porosity and permeability. These characteristic features further reduces the rate of infiltration, percolation, and leaching, thereby water table in the mining areas is decreased and causes the termination of water pathways by flooding or ponding in low lying valleys. One such example of water table lowering is Leslie County (Kentucky) where, the groundwater depletion in mining areas occurred over miles [97]. In another study in Pennsylvania, $9 \%$ of the total 2800 water supply channels within radius of $61 \mathrm{~m}$ of mines had reduced their water table [24]. Whereas the study of long wall mining operations of Greene (4 mines) and Washington county (3 mines) revealed that over the period of 2003-2008 affect 106 of 1214 undermined water supplies. Around $8.7 \%$ of these affected water supplies were within the 200 feet's of active mining sites [98]Similarly, another study conducted in Jharia coal mine region (India) had also shown instability in its water table [99]. Almost all of the tube wells in the mining area (Odrisha, India) dried during the summer season [100]. Additionally in case of Bangladesh, groundwater table is highly vulnerable to coal mining with a depletion rate of $>5 \mathrm{~m}$ (Table
3). Coal mining associated water tabledepletion is much more pronounced as compared to the domestic and irrigation groundwater abstraction rate, seen in Bangladesh and India (0.1-0.5 m/year) $[102,103]$. It is affected either by dewatering of underground mining voids or by seepage of water from saturated grounds to the mineshafts.

The problem of water table depletion is much more severe in arid and semi-arid regions, where small-scale mining leads to the dryness of springs, termination of river channels and drought. Semiarid regions of Anhui, Hebei, Henan, and Shandong (China) are its example, where coal extraction of last 50 years had shown severe water shortage [104].

It is relatively less severe as roadway stacks and room and pillar mining adopted in this case can reduce the drop of the water table in unconfined aquifers [96]. However, continued coal mining on large scale by longwall caving method formed the fractures that allow the rapid mine inflows following the surface subsidence and groundwater depletion. As in the case of Northern Shanxi (China) coal basin, the failure of surface strata connects the water aquifers by joining faults that cause the groundwater to drain into surface water or springs. One such example is the Janci spring of Shanxi Province (China), where continued mine pit drainage rapidly decline its groundwater table [13]. Since the year 2000, observed water decline due to extensive coal extraction in Yulin-Shenmu area was 6-9 $\mathrm{m}$, whereas in the area of Shenmu-Fugu the reported drop of the water table was up to $10 \mathrm{~m}$ (Table 3) [96]. One ton of coal mining in China deplete water resources by $1.32 \mathrm{~m}^{3}$ [19]. Since 1960 , due to extensive coal mining, China had observed a drop of $1 \mathrm{~m} /$ year in its water table, in the most affected areas of Hai River basin, Liao Songhua lowland and Northwest deserts within Gansu province [105].

This over-exploitation of water resources can be a severe damage to geological conditions. The most pronounced effect is the observed phenomenon of land subsidence (Section 1.4). For example, extensive pumping $\left(96 \mathrm{~m}^{3} / \mathrm{min}\right)$ in the Ordovician limestone aquifers (Hebei province) caused a depression cone of about $10 \mathrm{~km}$ (radius), affecting the drinking water shortage to a population of 100,000 occupies [106]. Another example is the decline of water flow that leads towards the drought. For instance in the case of Jinci spring, China coal mining destruct the hydrological system and causes a sudden decrease in its water flow up to $0.5 \mathrm{~m}^{3} / \mathrm{s}$ (1980s). By the time, this situation becomes more worsened with a decline inclination of $0.26 \mathrm{~m}^{3} / \mathrm{s}(1990)$ to $0.14 \mathrm{~m}^{3} / \mathrm{s}$ in 1992. Water of Jinci Spring area was completely dehydrated in 1994 [13]. Overall coal mining 
activities disparately interrupts both local and regional groundwater Table 1 obligatory preventive measures are not taken, such interruptions can lead towards intensive imbalance of water footprint [107-109].

\subsection{Backfill and dewatering: causes of flooding}

In case of groundwater, large-scale mining leads to the cracks and fracturing of overlying/underlying strata, where further stress and joining of such features leads to the land subsidence, and causes a cone of depression, which seizes the water flow and enhances the infiltration and precipitation in aquifers that results into flooding also known as artificial aquifers. To provide a safe working zone this flooding/inrush require dewatering. For example, the hard coal area of Ruhr (Germany) requires a pumping rate of $48-54 \mathrm{Mm}^{3} / \mathrm{a}$, which is significantly higher than the normal flow rate of $<5 \mathrm{~m}^{3} / \mathrm{h}$ [57].

For instance, extraction of coal from theZwartberg and WinterslagMines inBelgium caused an upward lift of about $10 \mathrm{~mm} /$ year, which resulted in flooding of ZwartbergMine. As the water level of ZwartbergMine increased, it resulted in flooding of the neighboring WinterslagMine. The overflow water was pumped at a rate of $7000 \mathrm{~m}^{3} /$ day to make Zwarting Mine operational [69].

The degree of water inrush is directly relatedto the thickness and permeability of the coal seams, their depths and head pressure. If the coal seam is fragile and its structural integrity is low than fractures can easily develop within the thick coal seam that will increase the flow of water inrush [110]. Similarly, deep mining $(>1000 \mathrm{~m})$ of North China plain induced greater discharge of water bearing strata through geological drains [111]. On the other hand, high-pressure groundwater can burst out due to explicit features of aquifers, geological characteristics and failure of mining strata. About $80 \%$ of water inrush cases are related to geological fault zones [112]. Because of inrush incidents of China, the maximum-recorded water inflow was $2053 \mathrm{~m}^{3}$ / min.

These water inrushes result in the elevation of water table known as groundwater rebound. This rebound is either the rise in groundwater due to cessation of pumping activities also known as passive (internal flooding) or active flooding (external flooding) in which water inrush takes place [113]. In case of France, where half of coal basins are flooded, mine water of these French mines drain into surface water bodies including rivers $(95 \%)$, lakes $(4 \%)$ and sea water $(1 \%)$ [57]. If we take an example of China, water inrush incidents can be divided into four major categories i.e. 1) water inundations due to limestone aquifers $(92.3 \%), 2)$ surface water flooding $(4.9 \%), 3)$ alluvial water flooding $(1.4 \%)$ and sandstone triggered inflow (1.4\%) [114]. If this rebound is not pumped out or drained through adits, the water table will raise to a level where inflow and outflow are equalized. This rebound process of groundwater also depends upon the coal stratum, size and geological features of the mining areas. For instance, observations of Ruhr (Germany) revealed that low permeable clay mineral formations in mining areas increase the speed of rebound [113].

Another example is of Northern China, where higher water pressure, thin seam strata and geological fractures and faults in Permo-Carboniferous coal seams resulted in the rise of the regional water table and accounted for massive flooding [106] About 285 of 600 coalmines of China having coal reserves of 25 billion tons are under serious threat of water inrush. One hundred and twenty-two such incidents were reported during the period of 1950-1990, and it was estimated that these caused economic lossesof about 180 million US dollars [106,115]. Karst water intrusion innorthern China affected 130 mines that may halt the extraction of more than 15 billion tons of coal [116]. These intrusions cause over 50 mines to be flooded for the last 30 years. Water inrush incidence of Barakpukuria (Bangladesh) in 1996 is another example of groundwater flooding in mines.

Such intensive inrushes require dewatering of mine aquifers. For example, intensive flooding in Barakpukaria coal mine area requires continuous dewatering at the rate of $1500-1600 \mathrm{~m}^{3} / \mathrm{h}$ [17]. Such excessive water withdrawals may affect hydrological system via land subsidence, depletion of groundwater table or reversal of groundwater flow directions, or diversion in surface water channels [96], that had a significant hydrological and ecological stress on regional water regime.

Continuous extraction and dewatering creates a cone of depression and can reduce the hydrological gradient thus requiring backfilling. Now, if the water table is towards the river, meaning that the hydraulic gradient of the aquifer is towards the stream, the groundwater will flow into the river, the stream in this case is called gaining stream. When the opposite situation is happening and the water from the river is, leaking into the aquifer the stream is considered losing stream. Once rebound is recovered to a level that surface discharges are taking place, it causes the water pollution (either of overlying aquifers or of surface watercourses) and degree of pollution is dependent to the nature of the 
discharge. As reported by Ref. [113], mine water of hard coal (bituminous and anthracite coal) mines substantially oxidized sulfate minerals and in connection with drinking water resources, and increases itsFe and $\mathrm{SO}_{4}^{2-}$ concentrations.

\subsection{Creation of new hydrological environments}

New hydrological environments are created due to land disturbance, non-permeable or less permeable conditions, recharging and mixing of local ground and surface water [94]. For instance in case of Huanghuaihai Plains (China), due to massive subsidence surface of shallow depth coalmineswere collapsedinto water ponds. These water ponds by the influence of surface water and precipitation converted into marshlands [87]. Similarly, subsidence around Barapukuria Coal Mining area of Bangladesh transformed the trenches into artificial lakes of low quality water [70]. Furthermore, subsurface mining (mountain top removal) as result of valley fills altered the local channels of water flow. In such cases, valley fills act as headwater aquifer for local surface and groundwater and make it to flow to the underneath. The hydraulic barrier in the form of coarse overlying strata increase the storage capacity that in turn increases retention time and enhanced supplementary exposure of water rock interactions. Such phenomenon occurred in the Southern Coalfields of New South Wales, Australia, where intensive connectivity of surface and groundwater enhance water-rock interactions [60]. These water rockinteractions might include dissolution of carbonates by rock weathering and redox reaction of metals bearing oxides and hydroxides that enrich dissolved solids and metallic content. The resultant chemical modifications are more pronounced in shallow groundwater [85]. In another case, dewatering of Upper Silesian coal mines in Polandresults in the discharge of alkaline water into river tributaries of Upper Wisla (Vistula) and Upper Odra (Oder)that enrichthe tributaries withhigh concentration of $\mathrm{Na}^{+}, \mathrm{SO}_{4}^{2-}$, and $\mathrm{Cl}^{-}$[58]. Similarly, in Spain, coal dewatering of flooded mines created a new hydrological system with high concentrations of major ions $\left(\mathrm{HCO}_{3}^{2-}, \mathrm{SO}_{4}^{2-}, \mathrm{Ca}^{2+}\right.$, and $\left.\mathrm{Mg}^{2+}\right)$ [58].

\section{Major water-related accidents in coal mining regions}

Coal mining can be a complex and lethal process. Traditional and poor mining practices can cause severe accidents to, and deaths of, miners. These incidents are due to mud sliding, coal dust and gas explosions, poisoning and suffocation, roof and blastingaccidents, and flooding. The causes and different socio-economic and environmental concerns with respect to these accidentsare reported in Table 4.

Mortality rates can be very high in coal mining areas. In 2003, the global production of 5 billion tons of coal was achieved with a causality rate of 8000 miners [110]. Approximately $80 \%$ of global coalrelated fatalities were reported for China, the largest global coal producer [118]. Deaths rate per million tons of coal of Turkey, China and US were 7.22, 1.27, and 0.02 , respectively. During the period 2001-2010, improvements in mine safety measures made by government of China reduced the fatality rate, but it stillhad highest rate of 0.25 fatalities/million tons, 10 and 87 times the reported fatalities for India and USA [119]. Coal mining-linkedcausalities in China have been reported to includeroof collapses, gas outbursts and explosions, poisoning and suffocation, water leakages, mine flooding and fire [120-122]. Among these fatal incidents, gas explosions have been reported to be the most severe [121]. The 2015 Soma Coal Mine accident in Turkey, with 300 causalities and more than 80 injuries, was one of the worst incident reported over the last 6 years [123]. Pakistan Central mines foundation reported thatan average each year 100-200 laborers have lost their lives in coal mining accidents. Many of these accidents were the result of untrained laborers and poor mining practices. About 328 fatal accidents (with 354 deaths) were reportedsince 2008-2013 in the Salt-range Coal Mines of Punjab, Pakistan. The reported data revealed that side wall collapses accounted for $38 \%$ of these fatalities, and roof collapses, $24 \%$ [124]. The main reason behind them is the instability due to rise in water level as well as poor management.

\section{Measurements and technological advancements that overcome environmental stress}

Coal plays an intermediate role in urbanization, industrialization and modernization, but its mining, transportation and utilization has had serious environmental impacts in many areas. The concept of "sustainable mining capacity" [125], in which the aim is to achieve maximum economic gain with minimal ecological loss, has been introduced to this industry. The implementation of regulatory measure and technological advances can help to achieve "sustainable capacity of coal mining" [125]. The regulatory measures that can be taken include the reclamation of land, soil and water treatment facilities, use of mine water for different purposes, 
construction of dams to protect the direct release of coal mine waters into surface bodies, segregation of useful metal(loid) elements and reduction of contamination by re-sing or remaining waste rocks and mine drainage. Backfilling and afforestation are two most practiced and economically viable methods of land reclamation [126,127]. Such activities reduce soil erosion and water runoff, and improve soil, water, and air quality in the mining area. One such example is Jharia coalfields (India), where afforestation via selective planation have reduced soil erosion and pollutants in the surrounding of mining areas [128]. In America under SMARCA (surface mining control and reclamation act of 1977) office of surface mines has provided $\$ 7.2$ billion to reclaimed 120 ha of abandoned mine land. Following this during the term 1978-2009, SMARCA has reclaimed an area of 500,000 ha [129]. Germany has focused afforestation of former coal mining areas whereas China has favored reclamation of such areas for agriculture [129]. An example of remediation occurs in the UK, where 53 coal mine water treatment plants manage and remediate over $140,000 \mathrm{~m}^{3} /$ day mine water by removing over 18,000 tons of iron [130]. In terms of re-use, coal mine waste rock (CMWR) from the Tiefa, China coalfields is used in brick making, power generation, subsidence rehabilitation and as fuel mixture. These bricks plants produce 1.6 billion bricks per year by using 1.377 Mt CMWR with a net profit of 49.43 .5 yuan/year. This brick making facility reclaimed 2.67ha land from CMWR. The net profit for power generation is 9 yuan and of fuel admixture is 19.53 million yuan/year [131]. An example of technological advancement can also be seen in case of China, where shifting to more advanced and modern mining practices has resulted in a reduction of the death toll of coal mining accidents from 5.07 to 0.25 deaths/ton. In some cases, restoration of closed and abandoned sites to their prior mine status is not effective, but the land can be converted into recreational sites. Recycoal project, UK is one of such exemplary body that converts many of abandoned coalmines into recreational sites. The restoration of Barnburgh site, Hesley Wood site (Sheffield) Northumberland coal mining areas into public parks are such achievement [129].

Direct coal consumption carried out in 20th century halted when environmental concerns like global warming came to the forefront. Diminishing non-renewable resources and their related impacts on environment paved the way for concept of sustainable development which states efficient use of resources in environment friendly way. In this scenario, the recent hike in electricity prices and energy crises faced by Pakistani population could only be overcome if the government utilize this potential reserve of about 185 billion tons, to the country's energy mix. However, practiced traditional mining can cause the above addressed problems. The projection of technical advancement as well as environmental management measurescan advance the practiced mining activities and restore the mining industry in a sustainable way. Hence, being a late entrant Pakistan can benefit from the clean coal technologies available today.

\section{Conclusions}

Coal is an important global energy fuel, but the coal mining industry faces major global challenges that need to be addressed. We have presented here an overview of published data on the measurable environmental impacts of coal mining with a major focus on water resource development. Production of acid mine drainage, land subsidence, flooding, new hydrological zonations, degradation of water quality and depletion of water tables are the major challenges of coal mining. However, moves towards sustainable mining can bring improve industrial growth, protect environmental and human health and protect surface and subsurface environments.

\section{Conflict of interest}

None declared.

\section{Ethical statement}

Authors state that the research was conducted according to ethical standards.

\section{Funding body}

None.

\section{Acknowledgements}

We would like to acknowledge Department of Environmental Sciences, Quaid-i-Azam University, Islamabad especially Environmental Hydro geochemistry Lab, and Environment \& Sustainability Institute, University of Exeter for the technical support and helpful comments throughout the write up of review article.

\section{References}

[1] Hancock S, Wolkersdorfer C. Renewed demands for mine water management. Mine Water Environ 2012;31(2): 147-58. 
[2] Li X, Cao L, Zhao X. Assessment of potential impact of tunneling on the groundwater in Epi-Fissure-Karst-Zone and ecological environment. Environmental Earth Sciences 2012;66(3):967-76.

[3] Nijhuis M, Kendrick R. Can coal ever be clean. 2014. Retrieved, . [Accessed 7 October 2015].

[4] Cardoso A. Behind the life cycle of coal: socio-environmental liabilities of coal mining in Cesar, Colombia. Ecol Econ 2015;120:71-82.

[5] WCA. Coal facts 2014. London: World Coal Association; 2014.

[6] Choi T-M. Sustainable management of mining operations with accidents: a mean-variance optimization model. Resour Pol 2015;46:116-22.

[7] Limbri H, Gunawan C, Rosche B, Scott J. Challenges to developing methane biofiltration for coal mine ventilation air: a review. Water, Air, Soil Pollut 2013;224(6):1566.

[8] Phillips J. Applying a mathematical model of sustainability to the Rapid Impact Assessment Matrix evaluation of the coal mining tailings dumps in the Jiului Valley, Romania. Resour Conserv Recycl 2012;63:17-25.

[9] Pandey B, Agrawal M, Singh S. Assessment of air pollution around coal mining area: emphasizing on spatial distributions, seasonal variations and heavy metals, using cluster and principal component analysis. Atmospheric pollution research 2014;5(1):79-86.

[10] Younger PL, Banwart SA, Hedin RS. Chapter three mine water hydrology. Mine Water 2002:127-270.

[11] Alam MJ, Ahmed A, Khan M, Ahmed B. Evaluation of possible environmental impacts for Barapukuria thermal power plant and coal mine. J Soil Sci Environ Manag 2011; 2(5):126-31.

[12] Schellenbach WL, Krekeler MP. Mineralogical and geochemical investigations of pyrite-rich mine waste from a kyanite mine in Central Virginia with comments on recycling. Environmental Earth Sciences 2012;66(5): 1295-307.

[13] Yang Y, Guo T, Jiao W. Destruction processes of mining on water environment in the mining area combining isotopic and hydrochemical tracer. Environ Pollut 2018;237:356-65.

[14] GWI. Global water intelligence, IDA desalination yearbook 2012-2013: market profile: 2012. 2014.

[15] China E. Environmental quality standards for surface water. China: MEP; 2002. GB3838-2002.

[16] Reza R, Singh G. Heavy metal contamination and its indexing approach for river water. Int J Environ Sci Technol 2010;7(4):785-92.

[17] Howladar MF. Coal mining impacts on water environs around the Barapukuria coal mining area, Dinajpur, Bangladesh. Environmental Earth Sciences 2013;70(1): 215-26.

[18] ley M, Pearson A, Smith G, Banton C. The impacts of coal mining subsidence on groundwater resources management of the East Midlands Permo-Triassic Sandstone aquifer, England. Q J Eng Geol Hydrogeol 2008;41(3):425-38.

[19] Alun G, Li S. Actual influence cost estimation of water resources in coal mining and utilization in China. Energy Procedia 2017;142:2454-60.

[20] Luo T, Otto B, Shiao T, Maddocks A. Identifying the global coal industry's water risks. Reducing Energy's Water Footprint, 26; 2014.

[21] Ghorbani Y, Kuan SH. A review of sustainable development in the Chilean mining sector: past, present and future. Int J Min Reclamat Environ 2017;31(2):137-65.

[22] Holley EA, Mitcham C. The Pebble Mine Dialogue: a case study in public engagement and the social license to operate. Resour Pol 2016;47:18-27.

[23] Kemp D, Bond CJ, Franks DM, Cote C. Mining, water and human rights: making the connection. J Clean Prod 2010; 18(15):1553-62.

[24] Tonsor SJ, Iannacchione AT, Hale AN, Bain D, Keener M, Pfeil-McCullough E, et al. The effects of subsidence resulting from underground bituminous coal mining, 2008-
2013: bituminous mine subsidence and land conservation act, act 54 amendments: 4 th five-year report. University of Pittsburgh; 2014.

[25] Wessman H, Salmi O, Kohl J, Kinnunen P, Saarivuori E, Mroueh U-M. Water and society: mutual challenges for eco-efficient and socially acceptable mining in Finland. J Clean Prod 2014;84:289-98.

[26] Cravotta C, Brady KB. Priority pollutants and associated constituents in untreated and treated discharges from coal mining or processing facilities in Pennsylvania, USA. Appl Geochem 2015;62:108-30.

[27] Karmakar H, Das P. Impact of mining on ground and surface waters. In: Paper presented at the 4th international mineral water association congress; 2012.

[28] Liu P, Hoth N, Drebenstedt C, Sun Y, Xu Z. Hydrogeochemical paths of multi-layer groundwater system in coal mining regions-using multivariate statistics and geochemical modeling approaches. Sci Total Environ 2017; 601:1-14.

[29] Bernhardt ES, Lutz BD, King RS, Fay JP, Carter CE, Helton AM, ..., Amos J. How many mountains can we mine? Assessing the regional degradation of central Appalachian rivers by surface coal mining. Environ Sci Technol 2012;46(15):8115-22.

[30] Nippgen F, Ross MR, Bernhardt ES, McGlynn BL. Creating a more perennial problem? Mountaintop removal coal mining enhances and sustains saline baseflows of Appalachian watersheds. Environ Sci Technol 2017;51(15):8324-34.

[31] Evans DM, Zipper CE, Hester ET, Schoenholtz SH. Hydrologic effects of surface coal mining in Appalachia (US). JAWRA Journal of the American Water Resources Association 2015;51(5):1436-52.

[32] Arnold M, Lindberg TT, Liu Y, Porter K, Hsu-Kim H, Hinton D, et al. Bioaccumulation and speciation of selenium in fish and insects collected from a mountaintop removal coal mining-impacted stream in West Virginia. Ecotoxicology 2014;23(5):929-38.

[33] Hopkins RL, Altier BM, Haselman D, Merry AD, White JJ. Exploring the legacy effects of surface coal mining on stream chemistry. Hydrobiologia 2013;713(1):87-95.

[34] Fox JF. Identification of sediment sources in forested watersheds with surface coal mining disturbance using carbon and nitrogen isotopes 1. JAWRA Journal of the American Water Resources Association 2009;45(5):1273-89.

[35] Jonek-Kowalska I, Turek M. Cost rationalization of maintaining post-industrial regions. Pol J Environ Stud 2013; 22(3).

[36] Younger PL. The adoption and adaptation of passive treatment technologies for mine waters in the United Kingdom. Mine Water Environ 2000;19(2):84-97.

[37] Ali J, Kazi TG, Tuzen M, Ullah N. Evaluation of mercury and physicochemical parameters in different depths of aquifer water of Thar coalfield, Pakistan. Environ Sci Pollut Control Ser 2017;24(21):17731-40.

[38] Infonet CGE. Mine geological environmental problems in China. 2003. Online at: http://www. cigem. gov. cn/englishver/files/net34. htm.

[39] Blowes D, Ptacek C, Jambor J, Weisener C. The geochemistry of acid mine drainage. Treatise on geochemistry 2003; 9:612.

[40] Feng W, Zhong M, Lemoine JM, Biancale R, Hsu HT, Xia J. Evaluation of groundwater depletion in North China using the Gravity Recovery and Climate Experiment (GRACE) data and ground-based measurements. Water Resour Res 2013;49(4):2110-8.

[41] Nordstrom DK. Hydrogeochemical processes governing the origin, transport and fate of major and trace elements from mine wastes and mineralized rock to surface waters. Appl Geochem 2011;26(11):1777-91.

[42] Chon H-T, Hwang J-H. Geochemical characteristics of the acid mine drainage in the water system in the vicinity of the Dogye coal mine in Korea. Environ Geochem Health 2000; 22(2):155-72. 
[43] Shim MJ, Choi BY, Lee G, Hwang YH, Yang J-S, O'Loughlin EJ, et al. Water quality changes in acid mine drainage streams in Gangneung, Korea, 10 years after treatment with limestone. J Geochem Explor 2015;159: 234-42.

[44] Zhengfu B, Inyang HI, Daniels JL, Frank O, Struthers S. Environmental issues from coal mining and their solutions. Min Sci Technol 2010;20(2):215-23.

[45] Hudson-Edwards KA, Jamieson HE, Lottermoser BG. Mine wastes: past, present, future. Elements 2011;7(6):375-80.

[46] Bian Z, Dong J, Lei S, Leng H, Mu S, Wang H. The impact of disposal and treatment of coal mining wastes on environment and farmland. Environ Geol 2009;58(3):625-34.

[47] Essilfie-Dughan J, Hendry MJ, Dynes JJ, Hu Y, Biswas A, Barbour SL, et al. Geochemical and mineralogical characterization of sulfur and iron in coal waste rock, Elk Valley, British Columbia, Canada. Sci Total Environ 2017;586: 753-69.

[48] Younger PL. Environmental impacts of coal mining and associated wastes: a geochemical perspective. Geological Society, London, Special Publications 2004;236(1): 169-209.

[49] Holla L, Barclay E. Mine subsidence in the southern coalfield. NSW, Australia: Department of Mineral Resources; 2000

[50] Harun-Or-Rashid HM, Urbi Z, Islam M. Environmental impact of coal mining: a case study on the Barapukuria coal mining industry, Dinajpur, Bangladesh. Middle East J Sci Res 2014;21(1):268-74.

[51] Bhuiyan MA, Islam M, Dampare SB, Parvez L, Suzuki S. Evaluation of hazardous metal pollution in irrigation and drinking water systems in the vicinity of a coal mine area of northwestern Bangladesh. J Hazard Mater 2010;179(1-3): 1065-77.

[52] Campaner VP, Luiz-Silva W, Machado W. Geochemistry of acid mine drainage from a coal mining area and processes controlling metal attenuation in stream waters, southern Brazil. An Acad Bras Ciências 2014;86(2):539-54.

[53] Moschini-Carlos V, Pompêo MLM, Lobo FdL, Meirelles ST. Impact of coal mining on water quality of three artificial lakes in morozini River basin (treviso, santa catarina state, Brazil). Acta Limnol Bras 2011;23:271-81.

[54] Wang W, Hao W, Bian Z, Lei S, Wang X, Sang S, et al. Effect of coal mining activities on the environment of Tetraena mongolica in Wuhai, Inner Mongolia, China-a geochemical perspective. Int J Coal Geol 2014;132:94-102.

[55] Zhou D, Wu K, Li L, Yu J. Impact of thick alluvial soil on a fractured water-conducting zone: an example from Huainan coal mine, China. J S Afr Inst Min Metall 2016; 116(5):431-40.

[56] Willscher S, Schaum M, Goldammer J, Franke M, Kuehn D, Ihling $\mathrm{H}$, et al. Environmental biogeochemical characterization of a lignite coal spoil and overburden site in Central Germany. Hydrometallurgy 2017;173:170-7.

[57] Gombert P, Sracek O, Koukouzas N, Gzyl G, Valladares ST, Frączek R, ..., Chamberlain S. An overview of priority pollutants in selected coal mine discharges in europe. Mine Water and the Environment; 2018. p. 1-8.

[58] Cooke CA, Schwindt C, Davies M, Donahue WF, Azim E. Initial environmental impacts of the Obed Mountain coal mine process water spill into the Athabasca River (Alberta, Canada). Sci Total Environ 2016;557:502-9.

[59] Equeenuddin SM, Tripathy S, Sahoo P, Panigrahi M. Hydrogeochemical characteristics of acid mine drainage and water pollution at Makum Coalfield, India. J Geochem Explor 2010;105(3):75-82.

[60] Dutta M, Saikia J, Taffarel SR, Waanders FB, de Medeiros D, Cutruneo CM, et al. Environmental assessment and nanomineralogical characterization of coal, overburden and sediment from Indian coal mining acid drainage. Geoscience Frontiers 2017;8(6):1285-97.

[61] Naicker K, Cukrowska E, McCarthy T. Acid mine drainage arising from gold mining activity in
Johannesburg, South Africa and environs. Environ Pollut 2003;122(1):29-40.

[62] Van Zyl H, Maree J, Van Niekerk A, Van Tonder G, Naidoo C. Collection, treatment and re-use of mine water in the Olifants River Catchment. J S Afr Inst Min Metall 2001; 101(1):41-6.

[63] Mativenga PT, Marnewick A. Water quality in a mining and water-stressed region. J Clean Prod 2018;171:446-56.

[64] Arshad SM, Tariqa SM, Shahzada M, Bakarb MZA, Waqasa M. Water characterisation of coal mining areas of Chakwal, Punjab, Pakistan. Pakistan Journal of Scientific and Industrial Research Series A: Physical Sciences 2015; 58(1):41-6.

[65] Akcil A, Koldas S. Acid mine drainage (AMD): causes, treatment and case studies. J Clean Prod 2006;14(12-13): 1139-45.

[66] Alakangas L, Andersson E, Mueller S. Neutralization/prevention of acid rock drainage using mixtures of alkaline byproducts and sulfidic mine wastes. Environ Sci Pollut Control Ser 2013;20(11):7907-16.

[67] Swer S, Singh O. Status of water quality in coal mining areas of Meghalaya. India. Bangladesh: IPHE; 2004.

[68] Hebblewhite B, Waddington A, Wood J. Regional horizontal surface displacements due to mining beneath severe surface topography. In: paper presented at the 19th int Conf. On ground control in mining; 2000.

[69] Vervoort A, Declercq P-Y. Upward surface movement above deep coal mines after closure and flooding of underground workings. International Journal of Mining Science and Technology 2018;28(1):53-9.

[70] Howladar MF. Environmental impacts of subsidence around the Barapukuria Coal Mining area in Bangladesh. Energy, Ecology and Environment 2016;1(6):370-85.

[71] Mei S, Poncos V, Froese C. Mapping millimetre-scale ground deformation over the underground coal mines in the Frank Slide area, Alberta, Canada, using spaceborne InSAR technology. Can J Rem Sens 2008;34(2):113-34.

[72] Zhang Z, Wang C, Tang Y, Zhang H, Fu Q. Analysis of ground subsidence at a coal-mining area in Huainan using time-series InSAR. Int J Rem Sens 2015;36(23):5790-810.

[73] Wang J, Lu C, Sun Q, Xiao W, Cao G, Li H, ..., Zhang B. Simulating the hydrologic cycle in coal mining subsidence areas with a distributed hydrologic model. Sci Rep 2017;7: 39983.

[74] Donnelly L, De La Cruz H, Asmar I, Zapata O, Perez J. The monitoring and prediction of mining subsidence in the amaga, angelopolis, venecia and bolombolo regions, antioquia, Colombia. Eng Geol 2001;59(1-2):103-14.

[75] Lamich $D$, Marschalko $M$, Yilmaz I, Bednářová $P$, Niemiec D, Kubečka K, et al. Subsidence measurements in roads and implementation in land use plan optimisation in areas affected by deep coal mining. Environmental Earth Sciences 2016;75(1):69.

[76] Marschalko M, Yilmaz I, Bednárik M, Kubečka K. Influence of underground mining activities on the slope deformation genesis: doubrava Vrchovec, Doubrava Ujala and Staric case studies from Czech Republic. Eng Geol 2012;147: 37-51.

[77] Harnischmacher S. Anthropogenic impacts in the Ruhr District (Germany): a contribution to Anthropogeomorphology in a former mining region. Geogr Fis Din Ouaternaria 2007:30:185-92.

[78] Maaß A-L, Schüttrumpf H. Long-term effects of mininginduced subsidence on the trapping efficiency of floodplains. Anthropocene 2018;24:1-13.

[79] Saini V, Gupta RP, Arora MK. Environmental impact studies in coalfields in India: a case study from Jharia coalfield. Renew Sustain Energy Rev 2016;53:1222-39.

[80] Sasaoka T, Takamoto H, Shimada H, Oya J, Hamanaka A Matsui K. Surface subsidence due to underground mining operation under weak geological condition in Indonesia. Journal of Rock Mechanics and Geotechnical Engineering 2015;7(3):337-44. 
[81] Baek J, Kim S-W, Park H-J, Jung H-S, Kim K-D, Kim JW. Analysis of ground subsidence in coal mining area using SAR interferometry. Geosci J 2008;12(3):277-84.

[82] Lee D-K, Mojtabai N, Lee H-B, Song W-K. Assessment of the influencing factors on subsidence at abandoned coal mines in South Korea. Environmental Earth Sciences 2013; 68(3):647-54.

[83] Hsu W-C, Chang H-C, Chang K-T, Lin E-K, Liu J-K, Liou YA. Observing land subsidence and revealing the factors that influence it using a multi-sensor approach in Yunlin County, Taiwan. Rem Sens 2015;7(6):8202-23.

[84] Sainsbury D. Analysis of river bed cracking above longwall extraction panels in the Southern Coalfield of New South Wales, Australia. In: Paper presented at the proceedings of the first southern hemisphere international rock mechanics symposium; 2008.

[85] Booth C. Groundwater as an environmental constraint of longwall coal mining. Environ Geol 2006;49(6):796-803.

[86] Oh H-J, Ahn S-C, Choi J-K, Lee S. Sensitivity analysis for the GIS-based mapping of the ground subsidence hazard near abandoned underground coal mines. Environmental Earth Sciences 2011;64(2):347-58.

[87] Fan T, Yan J, Wang S, Ruan S. The environment and the utilization the status of the subsidence area in the $\mathrm{Xu} \mathrm{Zhou}$, Yan Zhou and Huainan and Huaibei region of China. AGH journal of Mining and Geoengineering 2012;36(3): 127-33.

[88] Hu Z, Xiao W. Optimization of concurrent mining and reclamation plans for single coal seam: a case study in northern Anhui, China. Environmental Earth Sciences 2013; 68(5):1247-54.

[89] Andrews-Speed P, Yang M, Shen L, Cao S. The regulation of China's township and village coal mines: a study of complexity and ineffectiveness. J Clean Prod 2003;11(2): 185-96.

[90] Yang Y. A China environmental health project research brief. Coal mining and environmental health in China. 2007.

[91] Jankowski J, Spies B. In: Impact of longwall mining on surface water-groundwater interaction and changes in chemical composition of creek water. Paper presented at the Proc. XXXV IAH Congress (eds. L. Ribeiro et al.). Lisbon, Portugal, CD-ROM; 2007.

[92] Kay D, Barbato J, Brassington G, de Somer B. Impacts of longwall mining to rivers and cliffs in the Southern Coalfield. 2006.

[93] Chen G, Wang X, Wang R, Liu G. Health risk assessment of potentially harmful elements in subsidence water bodies using a Monte Carlo approach: an example from the Huainan coal mining area, China. Ecotoxicol Environ Saf 2019;171:737-45.

[94] Griffith MB, Norton SB, Alexander LC, Pollard AI, LeDuc SD. The effects of mountaintop mines and valley fills on the physicochemical quality of stream ecosystems in the central Appalachians: a review. Sci Total Environ 2012;417: $1-12$.

[95] Ping J, Yan S, Gu P, Wu Z, Hu C. Application of MIKE SHE to study the impact of coal mining on river runoff in Gujiao mining area, Shanxi, China. PloS One 2017;12(12): e0188949.

[96] Luo A, Hou Y, Hu X. Mining influence on underground water resources in arid and semiarid regions. In: Paper presented at the IOP conference series: earth and environmental science; 2018.

[97] Hutcheson SM, Kipp JA, Dinger JS, Sendlein LV, Carey DI, Secrist GL. Effects of longwall mining on hydrology, Leslie county, Kentucky Part 2: during-mining conditions. 2000.

[98] Witkowski MN. The effects of longwall coal mining on the hydrogeology of southwestern Pennsylvania. University of Pittsburgh; 2011.

[99] PanIGRahy BP, Singh PK, Tiwari AK, Kumar B. Variation in groundwater quality with seasonal fluctuation in Jharia coal mine region, Jharkhand, India. Curr World Environ 2015; 10(1).
[100] Mishra N, Das N. Coal mining and local environment: a study in talcher coalfield of India. Air Soil Water Res 2017; 10. 1178622117728913

[101] Guo W, Guo M, Tan Y, Bai E, Zhao G. Sustainable development of resources and the environment: mining-induced eco-geological environmental damage and mitigation measures - a case study in the henan coal mining area, China. Sustainability 2019;11(16):4366.

[102] Rodell M, Velicogna I, Famiglietti JS. Satellite-based estimates of groundwater depletion in India. Nature 2009; 460(7258):999.

[103] Shamsudduha M, Chandler R, Taylor R, Ahmed K. Recent trends in groundwater levels in a highly seasonal hydrological system: the Ganges-Brahmaputra-Meghna Delta. Hydrol Earth Syst Sci 2009;13(12):2373-85.

[104] Hanfu H, Changshen W, Haibo B, Zihe W. Water protection in the western semiarid coal mining regions of China: a case study. International Journal of Mining Science and Technology 2012;22(5):719-23.

[105] Yang X, Chen Y, Pacenka S, Gao W, Zhang M, Sui P, et al. Recharge and groundwater use in the North China Plain for six irrigated crops for an eleven year period. PloS One 2015; 10(1):e0115269.

[106] Zhang J. Investigations of water inrushes from aquifers under coal seams. Int J Rock Mech Min Sci 2005;42(3): 350-60.

[107] Dong Y, Zhao J. The calculation method for available water resources of northern Shaanxi [J]. J Arid Land Resour Environ 2013;3:017.

[108] Jinsheng Z, Jianhui W, Xueya D. The results of groundwater imbalance caused by mineral exploration and its controlling measures-Take the case of coal resources exploration in northern part of Shanxi. China Mining Magazine 2009; 18(12):52-5.

[109] Zhang N, Jin D, Shao D. Affection analysis of coal mining drainage for regional water resources: taking coal mining area of upper reaches of Yangwu river valley as example. Coal Geol Explor 2008;36(4):50-3.

[110] Gao R, Yan H, Ju F, Mei X, Wang X. Influential factors and control of water inrush in a coal seam as the main aquifer. International Journal of Mining Science and Technology 2018;28(2):187-93.

[111] Mao D, Liu Z, Wang W, Li S, Gao Y, Xu Z, et al. An application of hydraulic tomography to a deep coal mine: combining traditional pumping tests with water inrush incidents. J Hydrol 2018;567:1-11.

[112] Wang L-g, Miao X-x. Numerical simulation of coal floor fault activation influenced by mining. J China Univ Min Technol 2006;16(4):385-8.

[113] Westermann S, Dogan T, Reker B, Goerke-Mallet P, Wolkersdorfer C, Melchers C. Evaluation of mine water rebound processes in European Coal Mine Districts to enhance the understanding of hydraulic, hydrochemical and geomechanical processes. 2017.

[114] Shi L, Singh R. Study of mine water inrush from floor strata through faults. Mine Water Environ 2001;20(3):140-7.

[115] Zhang J-c, Zhang Y-z, Liu T. Rock mass permeability and coal mine water inrush. Beijing: Geological Publ House; 1997.

[116] Li G, Zhou W. Impact of karst water on coal mining in North China. Environ Geol 2006;49(3):449-57.

[117] Robinson P. Partizansk coal ash dam break and spillobservation. Southwest Research and Information Center; 2004.

[118] Chen H, Qi H, Long R, Zhang M. Research on 10-year tendency of China coal mine accidents and the characteristics of human factors. Saf Sci 2012;50(4):745-50.

[119] Chu C, Jain R, Muradian N, Zhang G. Statistical analysis of coal mining safety in China with reference to the impact of technology. J S Afr Inst Min Metall 2016;116(1):73-8.

[120] He X, Song L. Status and future tasks of coal mining safety in China. Saf Sci 2012;50(4):894-8. 
[121] Robson MG, Ming-Xiao W, Tao Z, Miao-Rong X, Bin Z, Ming-Qiu J. Analysis of national coal-mining accident data in China, 2001-2008. Publ Health Rep 2011;126(2): $270-5$.

[122] Sun L-h, Gui H-r. Establishment of water source discrimination model in coal mine by using hydrogeochemistry and statistical analysis: a case study from Renlou Coal Mine in northern Anhui Province, China. J Coal Sci Eng 2012;18(4): 385-9.

[123] Düzgün HS, Leveson N. Analysis of soma mine disaster using causal analysis based on systems theory (CAST). Saf Sci 2018;110:37-57.

[124] Ullah MF, Mahmood K, Akram MS. Coal mining trends and future prospects: a case study of Eastern Salt Range, Punjab, Pakistan. J Himal Earth Sci 2018;51(2A):87-93.

[125] Xie H, Wang J, Shen B, Liu J, Jiang P, Zhou H, et al. New idea of coal mining: scientific mining and sustainable mining capacity. J China Coal Soc 2012;37:1069-79.

[126] Fan L, Ma X. A review on investigation of water-preserved coal mining in western China. International Journal of Coal Science \& Technology 2018;5:411-6.

[127] Burger J. Sustainable mined land reclamation in the eastern US coalfields: a case for an ecosystem reclamation approach. In: Proceedings of the national meeting of the
American society of mining and reclamation, bismark, ND, USA; 2011. p. 113-41.

[128] Srivastava NK, Ram LC, Masto RE. Reclamation of overburden and lowland in coal mining area with fly ash and selective plantation: a sustainable ecological approach. Ecol Eng 2014;71:479-89.

[129] Sloss L. Coal mine site reclamation. IEA Clean Coal Centre; 2013. p. 978-92. CCC/216 ISBN.

[130] Johnston D, Potter H, Jones C, Rolley S, Watson I, Pritchard J. Abandoned mines and the water environment. Environment Agency Science project; 2008SC030136-41.

[131] Fan G, Zhang D, Wang X. Reduction and utilization of coal mine waste rock in China: a case study in Tiefa coalfield. Resour Conserv Recycl 2014;83:24-33.

[132] Mine Safety. https://www.sourcewatch.org/index.php/ Coal_mining_disasters/(Accesseddate: 21/03/2019.

[133] MSHA. (Mining safety and health administration) United State department of Labor. https://arlweb.msha.gov/ MSHAINFO/FactSheets/MSHAFCT2.html/. [Accessed 2 November 2018].

[134] QuangNinh coal mines, flooding in 2015, Vietnam. 2015. https://ejatlas.org/conflict/master-agua-quang-ninh-mines/. [Accessed 11 May 2018]. 